\title{
Mathematical Model, Simulation and Scale up of Batch Reactor Used in Oxidative Desulfurization of Kerosene
}

\author{
Ghazwan S. Ahmed ${ }^{\text {a }}$, Jasim I. Humadi ${ }^{b}$ and Ahmad A. Aabid ${ }^{c}$ \\ ${ }^{a}$ Chemical Engineering Department, College of Engineering, Tikrit University, Iraq \\ ${ }^{b}$ Petroleum and Gas Refining Engineering Department, College of Petroleum \& Minerals Engineering, Tikrit University, Iraq \\ ${ }^{c}$ Petroleum Reservoir Engineering Department, College of Petroleum \&Mining, Mosul University, Iraq
}

\begin{abstract}
In this paper, a mathematical model for the oxidative desulfurization of kerosene had been developed. The mathematical model and simulation process is a very important process due to it provides a better understanding of a real process. The mathematical model in this study was based on experimental results which were taken from literature to calculate the optimal kinetic parameters where simulation and optimization were conducted using gPROMS software. The optimal kinetic parameters were Activation energy $18.63958 \mathrm{~kJ} / \mathrm{mol}$, Pre-exponential factor $2201.34(\mathrm{wt})^{-0.76636} \cdot \mathrm{min}^{-1}$ and the reaction order 1.76636 . These optimal kinetic parameters were used to find the optimal reaction conditions which used to obtain a high conversion ( $\geq 99 \%)$. These optimal reaction conditions were reaction temperature $379.4{ }^{\circ} \mathrm{K}$ and reaction time $160 \mathrm{~min}$. A scale up to batch reactor was conducted using these optimal kinetic parameters and optimal reaction conditions and the results showed the best reactor size that can be used at a diameter of $1.2 \mathrm{~m}$.
\end{abstract}

Keywords: Mathematical model, Optimal kinetic parameters, Optimal reaction condition, Scale up, Batch reactor

Received on 27/05/2021, Accepted on 16/07/2021, published on 30/09/2021

https://doi.org/10.31699/IJCPE.2021.3.2

\section{1- Introduction}

Petroleum fractions contain different types of sulfur compounds (thiols, sulfides, and thiophenes) which is harmful compound to industry and environment [1].

These compounds are undesirable in petroleum fractions because they poison the catalyst in refinery and cause corrosion problems of internal combustion engines, also can emit $\mathrm{SO}_{2}$ in the combustion process $[1,2]$. Due to these disadvantages, many techniques have been developed for sulfur removal [3].

One of these techniques is the oxidative desulfurization (ODS) process which receives more attention because it operates under low operation conditions and doesn't consume hydrogen compared with hydrodesulfurization (HDS) [3]. Thus, the ODS process was studied by a lot of researchers using different catalysts and oxidants under different operating conditions and for different petroleum fractions [1-6]. Despite this experimental study, the simulation process and modeling become necessary because they provide a better understanding of the process [7].

The mathematical model of chemical processes involves several simulations and optimization that have many advantages such as estimation of the optimal operations without making any change on the real process. The process model is very efficient and profitable due to huge operations, control, safety, and design systems [8].
Finding a model which describes the experimental process under different process conditions consider a hard task challenge due to the experimental process contain several types of structure [16]. The mathematical model for a batch reactor can be complex due to the effect of many factors inside the reactor including mixing efficiency, size and shape of catalyst particles, kinetics on the catalyst surface, and pore diffusion within the framework effective or apparent reaction rate constant $[17,18]$. This study aims to find optimal kinetic parameters by applying a mathematical model and compared the results from the model with experimental results taken from the literature [9]. These kinetic parameters were used to find optimum reaction conditions which can give high conversion (>99\%). Also, this study includes the scale-up study of batch reactor based on optimal kinetic parameters and optimum reaction conditions to find the appropriate volume of the reactor.

\section{2- Methods and Methodology}

\subsection{Process Description}

The simulation results were made on experimental results taken from literature. The experimental section is consisting of a batch reactor for oxidative desulfurization of mercaptans from kerosene using merox on activated carbon catalyst in alkaline solution by air as oxidant. 
In order to easy for matching between experimental and simulation results some assumptions are used:

- The gaseous reactant exists in large excess and the liquid is saturated with gas at all times.

- Isothermal and constant pressure in the reactor.

- Steady state experimental unit.

- The reactant used in the model section consists of butanethiol and behaves as butanethiol in properties because it considers the most sulfur compound present in kerosene.

And the reaction can be stated below where thoils oxidize on the catalyst using air as an oxidant to produce disulfide which can remove easily by the adsorption process because it has high polarity. $\mathrm{RSH}+\mathrm{O}_{2} \rightarrow$ RSSR

\subsection{Mathematical Model}

The mathematical model is a set of algebraic and differential equations which can be solved by computational technique. The mathematical model of chemical processes involves several simulations and optimization that have many advantages such as estimation of the optimal operations without making any change on the real process. It can be developed by the formulation of the equations of mass and energy balance. A basic mathematical model will include a chemical reaction rate and combination mass and heat transfer equations with the kinetic equation [10].

The mathematical model can be started by making material balance about batch reactor concerning mercaptan concentration and this lead to [12]:

$\mathrm{t}=\int_{\text {CRSHO }}^{\mathrm{CRSH}} \frac{-d C_{R S H}}{\left(-r_{R S H}\right)}$

The reaction rate of chemical reaction could be taken into account by assuming $\mathrm{n}^{\text {th }}$ order kinetics.

$\left(-\mathrm{r}_{\mathrm{RSH}}\right)=\mathrm{k}_{\mathrm{app}} \mathrm{C}_{\mathrm{RSH}}{ }^{\mathrm{n}}$

The apparent kinetic constant was related to intrinsic kinetic constant by internal diffusion which was represented by the catalyst effectiveness factor $\left(\eta_{0}\right)$ as follows[11,12]:

$\mathrm{k}_{\mathrm{app}}=\eta_{\mathrm{O}} \mathrm{k}_{\mathrm{in}}$

By substitution of eq. (2) and (3) in eq. (1) and integration to this equation we can get the final expression which is:

$C_{R S H}=\left[C_{R S H O}{ }^{(1-n)}+(n-1) \cdot t \cdot k_{i n} \cdot \eta_{o}\right]^{\left(\frac{1}{(1-n)}\right)}$

The reaction rate constant $\left(\mathrm{k}_{\mathrm{in}}\right)$ can be calculated for ODS reaction by using the Arrhenius equation as follows:

$\mathrm{k}_{\mathrm{in}}=\mathrm{k}_{\mathrm{o}} e^{\left(\frac{-E}{R T}\right)}$

Eq. (4) contain effectiveness factor which can be calculated from the following equation that can be used for sphere particle $[11,12]$ :

$\eta_{\mathrm{O}}=\frac{3(\Phi \operatorname{coth}(\Phi)-1)}{\Phi^{2}}$

Effectiveness factor is a function of Thiele modulus which is calculated from the following equation [14]:

$\Phi=\frac{V_{p}}{S_{p}} \sqrt{\frac{(n+1)}{2} \frac{K_{i n} C_{R S H}{ }^{(n-1)}}{D_{e}}}$

Molecular diffusivity which is present in eq. (7) can be estimated from the equation [9]:

$\mathrm{De}=7.8^{*} 10^{-8} \frac{\psi B M B}{\left(\mathrm{v}_{R S H}\right)^{0.6}} \frac{T}{\mu}$

Where: $\psi B$ Non-aggregation coefficient. (This is equal to 1 for kerosene)

The molar volume of solute is calculated from the following equation $[11,12]$ :

$\mathrm{v}_{R S H}=0.285\left(\mathrm{v}_{c R S H}\right)^{1.048}$

The equations (1) to (9) were coded and simultaneously solved by gPROMS software.

The mathematical model was used to estimate the optimal kinetic parameters by minimizing the absolute error between experimental and predicted data.

In order to calculate the optimal kinetic parameters using the gPROMS software we must reduce the value of sum of square error (SSE) below [13]:

$\mathrm{SSE}=\sum_{1}^{i}\left(C_{\text {RSHexp }}-C_{\text {RSHpred }}\right)^{2}$

Where (i) represent the number of runs.

The mathematical model was containing several constant parameters which showed in Table $\mathbf{1}$.

Table 1. Values of constant parameters used in ODS model

\begin{tabular}{|c|c|c|c|c|}
\hline Parameter & \multicolumn{2}{|c|}{ Symbol } & Unit & Value \\
\hline $\begin{array}{l}\text { Initial } \\
\text { concentration }\end{array}$ & \multicolumn{2}{|l|}{ Co } & $\mathrm{Wt} \%$ & $\mathrm{Co}=0.0193$ \\
\hline Temperature & \multicolumn{2}{|c|}{$\mathrm{T} 1, \mathrm{~T} 2, \mathrm{~T} 3$} & ${ }^{\mathrm{o}} \mathrm{K}$ & $\begin{array}{l}\mathrm{T} 1=303, \mathrm{~T} 2=313, \\
\mathrm{~T} 3=323\end{array}$ \\
\hline Batch Time & $\begin{array}{l}\text { Tim1, } \\
\text { Tim3, } \\
\text { Tim5 }\end{array}$ & $\begin{array}{l}\text { Tim2, } \\
\text { Tim4, }\end{array}$ & Min & $\begin{array}{l}\operatorname{Tim} 1=5, \quad \operatorname{Tim} 2= \\
\text { 30, Tim3=60 } \\
\text { Tim4=90, } \\
\text { Tim5=120 }\end{array}$ \\
\hline Gas constant & $\mathrm{R}$ & & $\begin{array}{l}\mathrm{J} / \mathrm{mol} . \\
{ }^{\circ} \mathrm{K}\end{array}$ & 8.314 \\
\hline Molar volume & \multirow{2}{*}{\multicolumn{2}{|c|}{$\mathrm{v}_{R S H}$}} & $\mathrm{~g} / \mathrm{cm}^{3}$ & 96.38 \\
\hline Particle radius & & & $\mathrm{Mm}$ & 0.4 \\
\hline
\end{tabular}




\subsection{Scale up of Batch Reactor}

The model of batch reactor was developed by making material balance about reactor and energy balance for reactor and jacket which can be used to control the temperature of the reactor.

Material and energy balance will lead to the following set of ordinary differential equations [15]:

Material balance

$\frac{d c}{d t}=-k_{\text {in }} C^{n}$

Energy balance:

Reactor:

$\frac{d T}{d t}=\frac{U A}{\rho_{r} C p_{r} V}\left(T_{j}-T\right)+\frac{\Delta H r_{R S H} V}{\rho_{r} C p_{r} V}+\frac{\mu N^{2} V}{\rho_{r} C p_{r} V}$

Jacket:

$\frac{d T_{j}}{d t}=-\frac{U A}{\rho_{j} C p_{j} V_{j}}\left(T_{j}-T\right)+\frac{F}{V_{j}}\left(T_{j}-T_{n}\right)$

The following equations were acquired to solve these differential equations:

$\mathrm{A}=\pi D L$

$\mathrm{V}=\frac{\pi}{4} D^{2} L$

$V_{j}=\frac{\pi}{4}\left(D_{j}^{2}-D^{2}\right) L$

$\mathrm{L}=1.5 \mathrm{D}$

And

$D_{j}=1.3 D$

The viscosity of kerosene is used as a function of temperature which is estimated from the experimental result in literature:

$\mu=0.016 T-3.548$

The model of scale up of batch reactor contains several numerical values which showed in Table 2.

Table 2. Constants used in scale up model

\begin{tabular}{|c|c|c|c|}
\hline Parameter & Symbol & Unit & Value \\
\hline $\begin{array}{l}\text { Jacket solution heat } \\
\text { capacity }\end{array}$ & $\begin{array}{l}\mathrm{C}_{\mathrm{pj}} \\
\end{array}$ & $\mathrm{kJ} / \mathrm{kg} \mathrm{K}$ & 4.2 \\
\hline $\begin{array}{l}\text { Jacket } \quad \text { solution } \\
\text { density }\end{array}$ & $\rho_{j}$ & $\mathrm{Kg} / \mathrm{m}^{3}$ & 1000 \\
\hline $\begin{array}{l}\text { Reactor solution heat } \\
\text { capacity }\end{array}$ & $\mathrm{C}_{\mathrm{pr}}$ & $\mathrm{kJ} / \mathrm{kg} \mathrm{K}$ & 2.01 \\
\hline $\begin{array}{l}\text { Reactor solution } \\
\text { density }\end{array}$ & $\rho_{r}$ & $\mathrm{Kg} / m^{3}$ & 815.5 \\
\hline Impeller speed & $\mathrm{N}$ & RPM & 2000 \\
\hline Heat of reaction & $\mathrm{H}$ & $\mathrm{kJ} / \mathrm{mol}$ & 225.406 \\
\hline $\begin{array}{l}\text { Overall heat transfer } \\
\text { coefficient }\end{array}$ & $\mathrm{U}$ & $\mathrm{KW} / \mathrm{m}^{2}{ }^{\mathrm{o}} \mathrm{K}$ & 24 \\
\hline $\begin{array}{l}\text { Input } \\
\text { temperature }\end{array}$ & $\mathrm{T}_{\mathrm{n}}$ & ${ }^{\circ} \mathrm{K}$ & 420 \\
\hline
\end{tabular}

\section{3- Results and Discussion}

\subsection{Kinetic Parameters Estimation}

The optimal kinetic parameters which were calculated from the model by minimizing the function (SSE) were shown in Table 3 .

Table 3. Optimal kinetic parameters predicted from the model

\begin{tabular}{lll}
\hline Parameter & Value & Unit \\
\hline$n$ & 1.76636 & - \\
$\mathrm{E}$ & 18.63958 & $\mathrm{~kJ} / \mathrm{mol}$ \\
$\mathrm{k}_{\mathrm{o}}$ & 2201.34 & $(\mathrm{wt})^{-0.76636} \cdot \mathrm{min}^{-1}$ \\
\hline
\end{tabular}

\subsection{Simulation and Experimental Results}

The experimental and simulation results are present in Table 4. The simulation results were obtained from the model by gPROMS software. While the comparison between experimental and simulation results was shown in Fig. 1 to Fig. 3.

Table 4. Experimental and simulation results

\begin{tabular}{llllll}
\hline $\begin{array}{l}\text { Temperatur } \\
(\mathrm{K})\end{array}$ & $\begin{array}{l}\text { Batch } \\
\text { Time } \\
(\mathrm{min})\end{array}$ & $\begin{array}{l}\text { Concentration } \\
\text { by simulation } \\
(\mathrm{ppm})\end{array}$ & $\begin{array}{l}\text { Simulation } \\
\text { Conversion } \\
(\%)\end{array}$ & $\begin{array}{l}\text { Experimental } \\
\text { concentration } \\
(\mathrm{ppm})\end{array}$ & $\begin{array}{l}\text { Experimental } \\
\text { conversion } \\
(\%)\end{array}$ \\
\hline 303 & 5 & 144.17 & 25.30 & 152 & $\mathbf{2 1 . 2 4}$ \\
303 & 30 & 58.29 & 69.79 & 65.5 & $\mathbf{6 6 . 0 6}$ \\
303 & 60 & 31.55 & 83.65 & 31.5 & $\mathbf{8 3 . 6 7}$ \\
303 & 90 & 20.82 & 89.21 & 22.5 & $\mathbf{8 8 . 3 4}$ \\
303 & 120 & 15.20 & 92.12 & 14.5 & $\mathbf{9 2 . 4 8}$ \\
313 & 5 & 134.70 & 30.20 & 142.5 & $\mathbf{2 6 . 1 6}$ \\
313 & 30 & 48.02 & 75.11 & 50.5 & $\mathbf{7 3 . 8 3}$ \\
313 & 60 & 24.87 & 87.11 & 22.5 & $\mathbf{8 8 . 3 4}$ \\
313 & 90 & 16.09 & 91.66 & 14.5 & $\mathbf{9 2 . 4 8}$ \\
313 & 120 & 11.61 & 93.98 & 12.5 & $\mathbf{9 3 . 5 2}$ \\
323 & 5 & 124.87 & 35.30 & 133.5 & $\mathbf{3 0 . 8 2}$ \\
323 & 30 & 39.44 & 79.56 & 38.5 & $\mathbf{8 0 . 0 5}$ \\
323 & 60 & 19.67 & 89.80 & 18 & $\mathbf{9 0 . 6 7}$ \\
323 & 90 & 12.53 & 93.50 & 14 & $\mathbf{9 2 . 7 4}$ \\
323 & 120 & 8.96 & 95.35 & 10 & $\mathbf{9 4 . 8 1}$ \\
\hline & & & & &
\end{tabular}

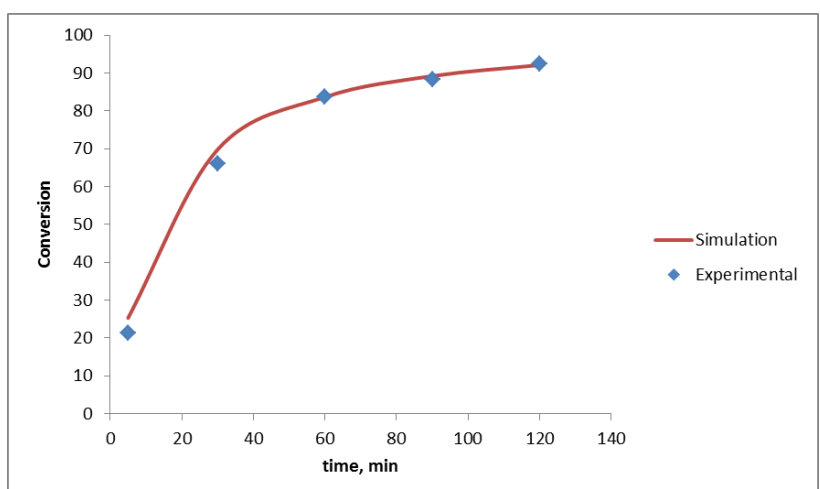

Fig. 1. Comparison between experimental and simulation results at $\mathrm{T}=303{ }^{\circ} \mathrm{K}$ 


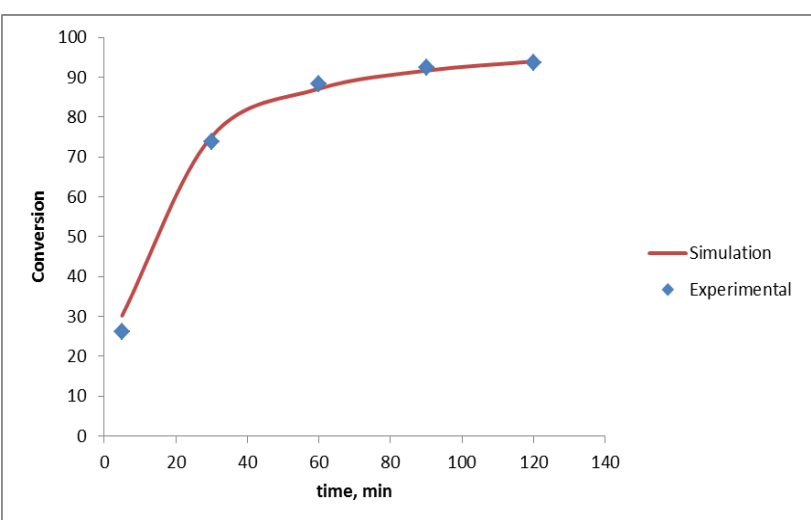

Fig. 2. Comparison between experimental and simulation results at $\mathrm{T}=313{ }^{\circ} \mathrm{K}$

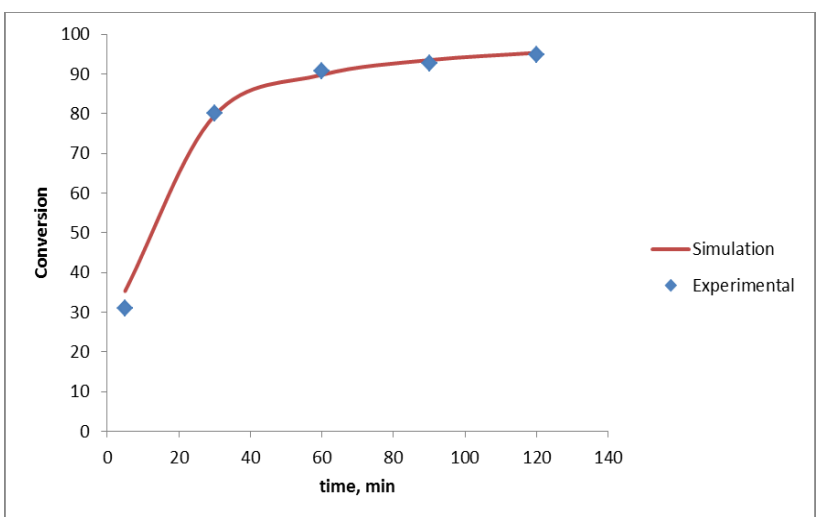

Fig. 3. Comparison between experimental and simulation results at $\mathrm{T}=323^{\circ} \mathrm{K}$

Fig. 1 to Fig. 3 above shows the effect of time on the conversion at different temperatures in addition to comparing experimental and simulation results. From these figures, we can observe that the conversion was increased by increasing the temperature and time, increasing temperature will increase the number of attractive molecules, and this leads to an increase in the conversion. Also, increasing the temperature will increase the rate constant according to the Arrhenius equation, and this lead to an increase in the reaction rate while increasing the time will increase the contact time between the reacting materials and the active sites of the catalyst $[12,13]$. Also, these figures showed the comparison between experimental and simulation results and we can see good matching between the simulation and experimental results because a few assumptions are used in this work and this assumption is used to ease the solving of the model where reducing the number of assumptions will increase the matching between experimental and simulation results.

\subsection{Optimal Reaction Conditions}

After getting the optimal kinetic parameters, these optimal parameters can be used in the model to find the optimal reaction conditions which can be used to get a high conversion $(\geq 99 \%)$ and these conditions are shown in Table 5.

Table 5. Optimal reaction conditions for high conversion

\begin{tabular}{lll}
\hline Parameter & Value & Unit \\
\hline Temperature & 379.4 & $\mathrm{~K}$ \\
Time & 160 & Min \\
Conversion & 99.135 & $\%$ \\
\hline
\end{tabular}

\subsection{Scale up of Batch Reactor}

The scale up of the batch reactor is studied under different reactor sizes to observe the effect of size on the concentration and temperature in the model.

The scale up model is used in gPROMS software to study the output temperature and concentration under different reactor sizes and these values were presented in Tables 6 and 7 below.

From these tables, the best value for diameter was at $\mathrm{D}=1.2 \mathrm{~m}$ due to that when $\mathrm{D}=1.2 \mathrm{~m}$, the value of concentration reach to minimum value and the temperature profile were more stable from the other value to diameter, in addition, consider the nearest value to the optimal temperature of high conversion. So that, from this study for scale up to batch reactor used here the diameter will be $1.2 \mathrm{~m}$ which can be depending it other dimensions of the reactor.

Table 6. Effect of the reactor size on concentration profile (concentration in ppm).

\begin{tabular}{lllllll} 
Time(min) & $\mathrm{D}=1(\mathrm{~m})$ & $\mathrm{D}=1.2(\mathrm{~m})$ & $\mathrm{D}=1.4(\mathrm{~m})$ & $\mathrm{D}=1.6(\mathrm{~m})$ & $\mathrm{D}=1.8(\mathrm{~m})$ & $\mathrm{D}=2(\mathrm{~m})$ \\
\hline 0.0 & 193 & 193 & 193 & 193 & 193 & 193 \\
10.0 & 78.94 & 83.33 & 86.88 & 89.83 & 92.27 & 94.35 \\
20.0 & 34.42 & 37.29 & 39.96 & 42.40 & 44.64 & 46.68 \\
30.0 & 19.18 & 20.68 & 22.15 & 23.60 & 25.00 & 26.35 \\
40.0 & 12.56 & 13.39 & 14.23 & 15.08 & 15.92 & 16.77 \\
50.0 & 9.09 & 9.57 & 10.08 & 10.61 & 11.13 & 11.68 \\
60.0 & 7.01 & 7.31 & 7.63 & 7.98 & 8.32 & 8.69 \\
70.0 & 5.65 & 5.84 & 6.06 & 6.29 & 6.53 & 6.78 \\
80.0 & 4.70 & 4.83 & 4.98 & 5.14 & 5.31 & 5.50 \\
90.0 & 4.00 & 4.09 & 4.19 & 4.31 & 4.44 & 4.58 \\
100.0 & 3.47 & 3.53 & 3.60 & 3.70 & 3.79 & 3.89 \\
110.0 & 3.05 & 3.09 & 3.15 & 3.22 & 3.29 & 3.37 \\
120.0 & 2.72 & 2.74 & 2.79 & 2.84 & 2.90 & 2.96 \\
130.0 & 2.44 & 2.46 & 2.49 & 2.53 & 2.58 & 2.63 \\
140.0 & 2.22 & 2.22 & 2.25 & 2.28 & 2.32 & 2.36 \\
150.0 & 2.03 & 2.02 & 2.04 & 2.07 & 2.10 & 2.14 \\
160.0 & 1.86 & 1.85 & 1.87 & 1.89 & 1.92 & 1.95 \\
\hline & & & & & & \\
\hline
\end{tabular}


Table 7. Effect of the reactor size on temperature profile (temperature in $\mathrm{K}$ )

\begin{tabular}{|c|c|c|c|c|c|c|}
\hline Time(min) & $\mathrm{D}=1(\mathrm{~m})$ & $\mathrm{D}=1.2(\mathrm{~m})$ & $\mathrm{D}=1.4(\mathrm{~m})$ & $\mathrm{D}=1.6(\mathrm{~m})$ & $\mathrm{D}=1.8(\mathrm{~m})$ & $\mathrm{D}=2(\mathrm{~m})$ \\
\hline 0.0 & 300.0 & 300.0 & 300.0 & 300.0 & 300.0 & 300.0 \\
\hline 10.0 & 354.04 & 348.53 & 343.94 & 340.10 & 336.84 & 334.05 \\
\hline 20.0 & 372.58 & 368.49 & 364.48 & 360.72 & 357.25 & 354.07 \\
\hline 30.0 & 378.79 & 376.62 & 374.04 & 371.30 & 368.53 & 365.82 \\
\hline 40.0 & 380.73 & 379.87 & 378.45 & 376.71 & 374.77 & 372.71 \\
\hline 50.0 & 381.19 & 381.11 & 380.46 & 379.45 & 378.20 & 376.75 \\
\hline 60.0 & 381.14 & 381.51 & 381.34 & 380.84 & 380.07 & 379.11 \\
\hline 70.0 & 380.90 & 381.56 & 381.70 & 381.51 & 381.09 & 380.48 \\
\hline 80.0 & 380.60 & 381.47 & 381.80 & 381.82 & 381.63 & 381.27 \\
\hline 90.0 & 380.27 & 381.33 & 381.78 & 381.94 & 381.90 & 381.71 \\
\hline 100.0 & 379.94 & 381.15 & 381.71 & 381.96 & 382.03 & 381.96 \\
\hline 110.0 & 379.60 & 380.97 & 381.62 & 381.94 & 382.07 & 382.09 \\
\hline 120.0 & 379.26 & 380.78 & 381.51 & 381.88 & 382.08 & 382.15 \\
\hline 130.0 & 378.91 & 380.59 & 381.39 & 381.82 & 382.05 & 382.17 \\
\hline 140.0 & 378.56 & 380.39 & 381.28 & 381.75 & 382.01 & 382.16 \\
\hline 150.0 & 378.20 & 380.20 & 381.16 & 381.67 & 381.97 & 382.14 \\
\hline 160.0 & 377.85 & 380.00 & 381.04 & 381.60 & 381.92 & 382.11 \\
\hline
\end{tabular}

\section{4- Conclusions}

In this study, a mathematical model was developed to simulate experimental results. The mathematical model is used to find the optimal kinetic parameters based on experimental results and then used them to find the optimal reaction conditions which can give high conversion. The optimal kinetic parameters and the optimal reaction conditions which was presented in this study is used to the scale up of batch reactor. The results showed that the best size to reactor which achieve the high conversion and temperature nearest to optimal value was at reactor diameter of $1.2 \mathrm{~m}$.

\section{Nomenclature}

$\mathrm{C}_{\mathrm{RSH}}$ : Mrcaptan concentration, $\mathrm{Wt} \%$.

$\mathrm{C}_{\mathrm{RSHO}}$ : Initial concentration of mercaptan, $\mathrm{Wt} \%$.

$\mathrm{T}$ : $\quad$ Temperature, ${ }^{\mathrm{O}} \mathrm{K}$.

t: $\quad$ time, min

$\mathrm{K}_{\mathrm{app}}$ : Apparent rate constant, (wt) ${ }^{-0.76636} \cdot \mathrm{min}^{-1}$.

$\mathrm{K}_{\mathrm{in}}$ : Intrinsic rate constant, $(\mathrm{wt})^{-0.76636} \cdot \mathrm{min}^{-1}$.

$\mathrm{K}_{\mathrm{o}}$ : Pre-exponential factor, $(\mathrm{wt})^{-0.76636} \cdot \mathrm{min}^{-1}$.

E: Activation energy, $\mathrm{kJ} / \mathrm{mol}$.

R: $\quad$ Gas constant, $\mathrm{J} / \mathrm{mol}{ }^{\circ} \mathrm{K}$.

$\mathrm{n}$ : $\quad$ Order of reaction.

$\eta_{\mathrm{O}}: \quad$ Effectiveness factor.

$\Phi: \quad$ Thiele modulus.

$\left(-\mathrm{r}_{\mathrm{RSH}}\right)$ : Reaction rate, Wt\%/sec.

De: $\quad$ Effective diffusivity, $\mathrm{Cm}^{2} / \mathrm{sec}$.

$\psi B$ : Non-aggregation coefficient.

$M B$ : Molecular weight of solvent, $\mathrm{g} / \mathrm{gmol}$.

$\mathrm{v}_{R S H}$ : Molar volume of mercaptan, $\mathrm{m}^{3} / \mathrm{mol}$.

$\mathrm{v}_{C R S H}$ : Critical molar volume of mercaptan, $\mathrm{m}^{3} / \mathrm{mol}$.
Viscosity, Pa.s.

$\mathrm{V}_{\mathrm{p}}: \quad$ Particle volume, $\mathrm{m}^{3}$

$\mathrm{S}_{\mathrm{p}}$ : $\quad$ External surface area of particle, $\mathrm{m}^{2}$.

$\mathrm{U}: \quad$ Overall heat transfer coefficient, $\mathrm{KW} / \mathrm{m}^{2}{ }^{\circ} \mathrm{K}$.

$\rho_{j}$ : $\quad$ Density of solution in jacket, $\mathrm{Kg} / \mathrm{m}^{3}$.

$C p_{j}$ : Heat capacity of solution in jacket, $\mathrm{kJ} / \mathrm{kg}^{\circ} \mathrm{K}$.

$V_{j}$ : Jacket volume, $\mathrm{m}^{3}$.

$\rho_{r}: \quad$ Density of solution in reactor, $\mathrm{Kg} / \mathrm{m}^{3}$.

$C p_{r}$ : Heat capacity of solution in reactor, $\mathrm{kJ} / \mathrm{kg}{ }^{\mathrm{o}} \mathrm{K}$.

$V: \quad$ Reactor volume, $\mathrm{m}^{3}$.

D: $\quad$ Reactor diameter, $m$.

L: $\quad$ Reactor height, $\mathrm{m}$.

$\mathrm{D}_{\mathrm{j}}$ : $\quad$ Diameter of jacket, $\mathrm{m}$.

F: $\quad$ Steam flow rate, $\mathrm{kg} / \mathrm{s}$.

$\mathrm{T}_{\mathrm{n}}$ : $\quad$ Temperature of input steam, ${ }^{\mathrm{o}} \mathrm{K}$.

$\mathrm{T}_{\mathrm{j}}$ : Jacket temperature, ${ }^{\circ} \mathrm{K}$.

$\mathrm{N}$ : $\quad$ Impeller speed, RPM.

$\Delta H: \quad$ Heat of reaction, $\mathrm{kJ} / \mathrm{mol}$.

SSE: $\quad$ Sum of square error

\section{References}

[1] J.M. Campos-Martin, M.C. Capel-Sanchez, P. PerezPresas and J.L.G. Fierro, "Oxidative Processes of Desulfurization of Liquid Fuels". Journal of Chemical Technology \& Biotechnology, vol. 85(7),pp. 879-890, March. 2010.

[2] N.M. Meman, B. Zarenezhad, A. Rashidi, H. Zeinab and E. Esmaeili, "Application of Palladium Supported on Functionalized MWNTs for Oxidative Desulfurization of Naphtha". Journal of Industrial and Engineering Chemistry, vol. 22, pp.179-184, Feb. $\underline{2015 .}$

[3] K. Yazu, A. Matsumura and S. Sato, "Oxidative Desulfurization of Naphtha with Hydrogen Peroxide in Presence of Acid Catalyst in Naphtha/Acetic Acid Biphasic System". Journal of the Japan petroleum Institute, vol. 53(4), pp. 251-255, 2010.

[4] C. Song, "An Overview of New Approaches to Deep Desulfurization for Ultra-clean Gasoline, Diesel Fuel and Jet Fuel". Catalysis Today, vol. 86(1-4), pp. 211263, Nov. 2003.

[5] Z. Wu and B. Ondruschka, "Ultrasound-assisted Oxidative Desulfurization of Liquid Fuels and its Industrial Application”. Ultrasonics Sonochemistry vol. 17(6), pp. 1027-1032, Aug. 2010.

[6] W. Liang, S. Zhang, H. Li and G. Zhang, "Oxidative Desulfurization of Simulated Gasoline Catalyzed by Acetic Acid-based Ionic Liquids at Room Temperature". Fuel Processing Technology, vol. 109, pp. 27-31, May. 2013.

[7] A.T. Nawaf, "Experimental and Modeling Study for Desulfurization of Light Gas Oil by Catalytic Wet Air Oxidation Process”. MSc. thesis, Tikrit University, Iraq, 2015. 
[8] H. Khalfalla, "Modeling and Optimization of Oxidative Desulfurization Process for Model Sulfur Compounds and Heavy Gas Oil". Philosophy of Doctor thesis, University of Bradford, UK, 2009.

[9] A. Farshi and Z. Rabiei, "Kinetic Study for Oxidation of Existing Mercaptans in Kerosene Using Impregnated Activated Carbon with MEROX Catalyst in Alkaline Solution". Petroleum \& Coal, vol. 47(1), pp. 49-56, Jan. 2005.

[10] M. Al-Dahhan, F. Larachi, M. Dudukovic and A. Laurent, "High Pressure Trickle Bed Reactors. A review". Industrial \& Engineering Chemistry Research, vol. 36(8), pp. 3292-3314, Aug.1997.

[11] G. Marroquín, J. Ancheyta and C. Esteban , "A batch Reactor Study to Determine Effectiveness Factors of Commercial HDS Catalyst". Catalysis Today, vol. 104(1), pp. 70-75, Jun. 2005.

[12] G.S. Ahmed, A.T. Jarullah, B.A. Al-Tabbakh and I.M. Mujtaba, "Design of an Environmentally Friendly Reactor for Naphtha Oxidative Desulfurization by Air Employing a New Synthetic Nano-Catalyst Based on Experiments and Modeling". Journal of cleaner production, vol. 257, pp. 120436, Jun. 2020.

[13] A.T. Jarullah, G.S. Ahmed, B.A. Al-Tabbakh and I.M. Mujtaba, "Enhancement of Light Naphtha Quality and Environment Using New Synthetic Nanocatalyst for Oxidative Desulfurization: Experiments and Process Modeling". Computers and Chemical Engineering, vol. 140, pp. 106869, Sep. 2020.

[14] R.J. Wijngaarden, A. Kronberg and K.R. Westertrep, "Calculation of Effectiveness Factor", Wiley-VCH: Veriag GmbH, 1998.

[15] R.O. Vargas and F. López-Serrano, "Modeling, Simulation and Scale-up of a Batch Reactor". In: Klapp J., Medina A. (eds) Experimental and Computational Fluid Mechanics. Environmental Science and Engineering. Springer, Cham. Jan. 2014.

[16] A.T. Jarullah, I.M. Mujtaba and A.S. Wood, "Kinetic Model Development and Simulation of Simultaneous Hydrodenitrogenation and Hydrodemetallization of Crude Oil in Trickle Bed Reactor". Fuel, vol. 90, pp. 2165-2181, Jun. 2011.

[17] J.A. Paraskos, J.A. Frayer and Y.T. Shah, "Effect of Holdup Incomplete Catalyst Wetting and Back Mixing During Hydro-Processing in Trickle Bed Reactors". Industrial \& Engineering Chemistry Process Design and Development, vol. 14(3), pp. 315322, Jul.1975.

[18] H.P. Hofman, "Multiphase Catalytic Packed-Bed Reactors". Catalysis Reviews Science and Engineering, vol. 17(1), pp. 71-117, 1978. 


\section{نموذج رياضي و محاكاة وتوسيع نطاق المفاعل الافعي المستخدم في عملية ازالة الكبريت بالاكسدة من الكيروسين}

غزوان صالح احمد 1, جاسم ابراهيم حمادي 2و احمد عبد السلام عابد 3

$$
\begin{aligned}
& 1 \text { قسم الهندسة الكيمياوية, كلية الهنسسة, جامعة تكريت, العرقاق }
\end{aligned}
$$

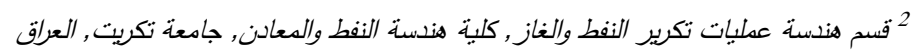

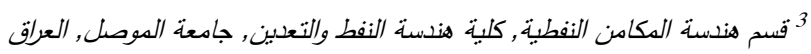

الخلاصة

في هذا البحث ، تم تطوير نموذج رياضي لإزالة الكبريت بالاكسدة من الكيروسين. يعد النموذج الرياضي

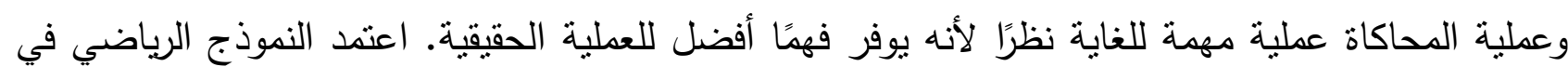

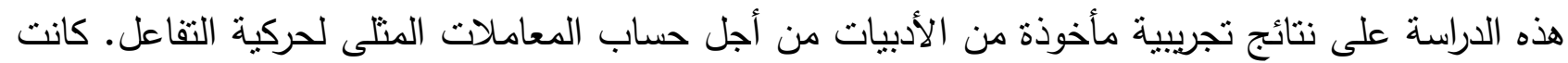

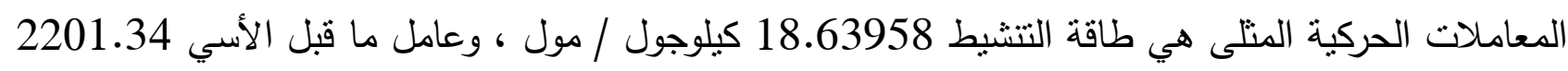

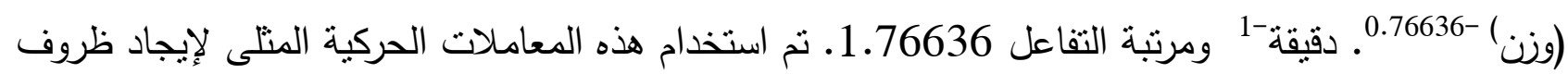

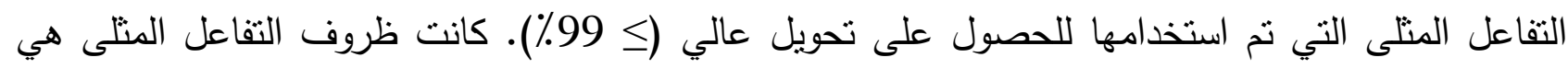
درجة حرارة التفاعل 379.4 كلفن وزمن التفاعل 160 دقيقة. تم إجراء توسيع نطاق للمفاعل الدفعي باستخدام هذه المعاملات الحركية المنلى وظروف التفاعل المنلى وأظهرت النتائج أفضل حجم مفاعل يمكن استخدامه نطاء بقطر 1.2 م.

الكلمات الدالة: نموذج رياضي, افضل المعاملات الحركية, افضل الظروف التثغيلية, توسيع نطاق, مفاعل دفعي 